D0\%B8\%D0\%BA режим доступа свободный [Электронный ресурс]. Дата обращения $\underline{27.02 .2017}$

7. BЭC URL: https://alternativenergy.ru/vetroenergetika/581-plyusy-minusyvetroenergetiki.html режим доступа свободный [Электронный ресурс]. Дата обращения $\underline{27.02 .2017}$

8. ДЭС URL: http://naukovedenie.ru/PDF/38tvn113.pdf режим доступа свободный [Электронный ресурс]. Дата обращения 27.02.2017

Степень износа ДЭС URL: http://dic.academic.ru/dic.nsf/ruwiki/900155 режим доступа свободный [Электронный ресурс]. Дата обращения 27.02.2017

\title{
Актуальность внедрения малых ГЭС с комбинацией СЭС в условиях Крайнего Севера
}

Местников Н.П., слушатель, ГАУ ДПО «Высшая икола инновационного менеджмента при Главе РС (Я)», г. Якутск E-mail: nikolai.miestnikov.96@mail.ru

\section{Научный руководитель: к.г.н., профессор Константинов А.Ф.}

Одной из серьезных проблем функционирования энергосистемы Якутии является то, что обособленность энергорайонов не позволяет рационально использовать структуру энергетического хозяйства республики централизованного электрообеспечения, повысить надежность энергоснабжения и создать конкурентную среду по производству электроэнергии. [2] Функционирование энергетики Севера республики характеризуется сложной транспортной схемой доставки топлива с несколькими перевалками. Высокая стоимость топлива в местах потребления, низкие технико-экономические показатели существующих энергоисточников малой мощности приводят к высокой себестоимости производства электроэнергии и тепла (в России ежегодно на завоз топлива в северные регионы затрачивается более 16 млрд. руб., в том числе в северные районы РС(Я)- свыше 7 млрд. руб., а протяженность пути составляет 500-600 суток и износ ДЭС на 40\%-60\%, несмотря на то, что на территории РС (Я) за год введутся в эксплуатацию 7 новых ДЭС). [2]

\section{Основные методы повышения показателей мошностей энергетики РС(Я)}

В данное время решениями данной проблемы являются комбинированные электрические станции, такие как [1]:

1. ДЭС + МГЭС (при непостоянных расходах воды в реке ДЭС + СЭС + МГЭС);

2. ДЭС + ВЭУ + СЭС;

3. МГЭС + ВЭС;

4. ДЭС + БПГЭС и т.д.

СЭС выполняет роль вспомогательного источника электроэнергии, доля электроснабжения которой составляет от 10\% до 20\% в основных СЭС, которые имеется у АО «Сахаэнерго». Следует отметить, что северный энергорайон отличается тем, что период полярной ночи начинается с 5-7 декабря по середине февраля, согласно данным по Усть-Янскому району. Поэтому СЭС вырабатывает электроэнергию в 
непостоянной основе в зависимости от продолжительности дня и погоды. Приводятся данные ТЭП СЭС-20 кВт с. Дулгалаах АО «Сахаэнерго» за 2015 год:

Таблица 1

\begin{tabular}{|c|c|c|c|}
\hline \multicolumn{5}{|c|}{ Выработка э/э в СЭС-20 кВт с. Дулгалаах, тыс. кВт*ч } \\
\hline Январь & Февраль & Март & Апрель \\
\hline $\mathbf{0}$ & $\mathbf{1 , 3 8 5}$ & $\mathbf{2 , 3 3}$ & $\mathbf{3 , 5 5 1}$ \\
\hline Май & Июнь & Июль & Август \\
\hline $\mathbf{4 , 0 1 9}$ & $\mathbf{2 , 7 8 1}$ & $\mathbf{2 , 5 7 8}$ & $\mathbf{1 , 7 5 6}$ \\
\hline Сентябрь & Октябрь & Ноябрь & Декабрь \\
\hline $\mathbf{2 , 2 2}$ & $\mathbf{1 , 6 3 7}$ & $\mathbf{0 , 7 4 9}$ & $\mathbf{0}$ \\
\hline
\end{tabular}

Следует отметить, что СЭС в период с 1 декабря по 31 января отключается, так как действует период «полярной ночи». Поэтому эксплуатация приостанавливается на 2 месяца.

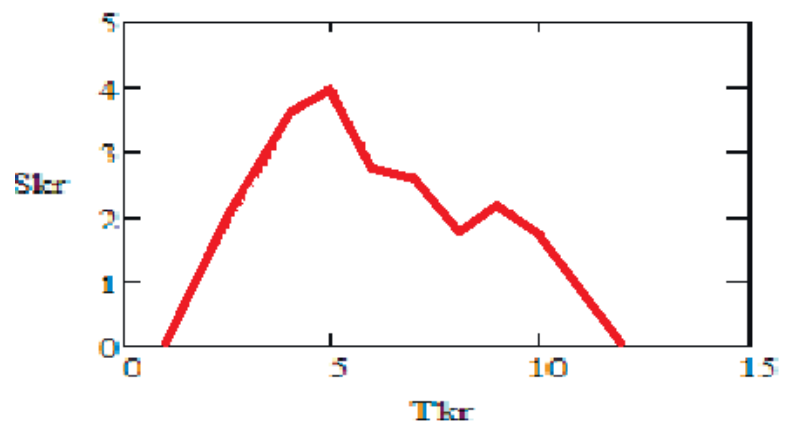

Рис. 1. Выработка э/э в СЭС-20 кВт с. Дулгалаах, тыс. кВт*ч

По рисунку видно, что основная активность СЭС находится с апреля по май и медленно падает в летнем сезоне. Населенный пункт Дулгалаах находится в районе Верхоянского хребта. По оси Tkr отмечены номера месяцев, например. 1- это январь.

Рассмотрим выработку электроэнергии в СЭС-40 кВт с. Эйик Оленекского района. Отметим, что Оленекский район находится в полном плоскогорье и имеет горы малой высоты.

Таблица 2

\begin{tabular}{|c|c|c|c|}
\hline \multicolumn{5}{|c|}{ Выработка э/э в СЭС-40 кВт с. Эйик, тыс. кВт*ч } \\
\hline Январь & Февраль & Март & Апрель \\
\hline $\mathbf{0 , 0 0 4}$ & $\mathbf{1 , 1 1 8}$ & $\mathbf{2 , 3 6 5}$ & $\mathbf{7 , 7 1 1}$ \\
\hline Май & Июнь & Июль & Август \\
\hline $\mathbf{6 , 1 1 7}$ & $\mathbf{5 , 0 0}$ & $\mathbf{4 , 0 5}$ & $\mathbf{3 , 1 3 1}$ \\
\hline Сентябрь & Октябрь & Ноябрь & Декабрь \\
\hline $\mathbf{3 , 7 2}$ & $\mathbf{1 , 4 6 4}$ & $\mathbf{0 , 3 1 4}$ & $\mathbf{0 , 1 2}$ \\
\hline
\end{tabular}

Следует отметить, что СЭС-40 кВт не была отключена и функционировала полный год. Считаю, что это связано с высокой мощностью выработки э/э в данном населенном пункте. 


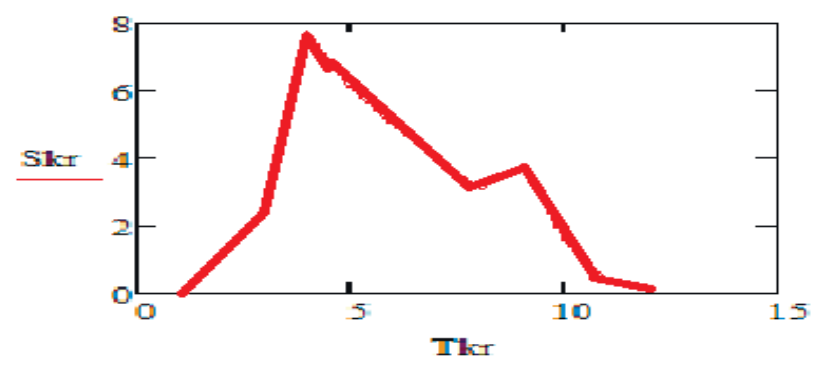

Рис. 2. Выработка э/э в СЭС-40 кВт с. Эйик, тыс. кВт*ч

Рассмотрим выработку электроэнергии в СЭС-40 кВт с. Эйик Оленекского района. Отметим, что Оленекский район находится в полном плоскогорье и имеет горы малой высоты. Таким образом, МГЭС и СЭС для условий Крайнего Севера могут быть вспомогательными источниками энергии. В данное время северный энергорайон снабжается э/э компанией АО «Сахаэнерго». В случае постройки МГЭС при комбинации ДЭС + МГЭС доля электроснабжения для МГЭС может составлять 100\%, что и увеличивает надежность электроснабжения, несмотря на погодные условия, уменьшает износ ДГУ и снижает потребление дизельного топлива для ДГУ на летний период. Следует отметить, что расход воды в любых реках не постоянна.

\section{Расчет СЭС для МГЭС}

Доля электроснабжения на СЭС в населенных пунктах обычно составляет 1020\%. Существуют два вида солнечных панелей:

1. Поликристаллические (далее - ПКП);

2. Монокристаллические (далее - МКП).

1. Выработка э/э выше на $10 \%$ по показаниям I (тока) [A] и S (полной мощности) [MBA];

2. Выработка э/э выше при любой погоде;

3. Но соответственно дороже на $18 \%$ от стоимости ПКП.

По опыту эксплуатации СЭС в компании АО «Сахаэнерго» известно, что использование аккумуляторных батарей (далее - АКБ) для автономной работы СЭС увеличивает стоимость на 40-60\%. Поэтому следует внедрить СЭС без АКБ, чтобы уменьшить стоимость и срок окупаемости проекта по ВИЭ. Следовательно, возможно общее подключение СЭС на общей шине в:

1. ДЭС;

2. МГЭС.

Согласно данному анализу в таблицах, видно, что СЭС следует подключить к ДЭС для увеличения надежности СЭС и увеличения периода работы СЭС от 4 до 12 месяцев. По опыту эксплуатации СЭС компанией АО «Сахаэнерго» известно, что доля ЭС населенного пункта для СЭС составляет от 10\% до 20\%.

Средняя стоимость полной смета проекта для СЭС в условиях РС(Я) составляет 140000 - 150000 руб./кВт э/э (с учетом СМР, НДС, оборудования и т.д.), согласно данным отдела ОВАИЭиНТ АО «Сахаэнерго».

Следовательно, для выбранных сел нужно: 
Таблица 3

\begin{tabular}{|l|c|c|c|c|}
\hline \multicolumn{5}{|c|}{ Мощность и стоимость проекта СЭС } \\
\cline { 1 - 2 } $\begin{array}{l}\text { Населенный } \\
\text { пункт }\end{array}$ & $\begin{array}{c}\text { Максимальная } \\
\text { летняя нагрузка, } \\
\text { кВт }\end{array}$ & $\begin{array}{c}\text { Доля ЭС для } \\
\text { СЭС, \% }\end{array}$ & $\begin{array}{c}\text { Мощность СЭС, } \\
\text { кВт }\end{array}$ & $\begin{array}{c}\text { Стоимость } \\
\text { проекта, млн. руб. }\end{array}$ \\
\cline { 1 - 1 } Белая Гора & $\mathbf{8 3 0}$ & \multirow{2}{*}{$8,1-9,6 \%$} & $\mathbf{8 0}$ & $\mathbf{1 2}$ \\
\cline { 1 - 2 } $\begin{array}{l}\text { Себян- } \\
\text { Кюель }\end{array}$ & $\mathbf{1 2 2}$ & $\mathbf{1 0}$ & $\mathbf{1 , 5}$ \\
\cline { 1 - 2 } Оленек & $\mathbf{8 4 0}$ & $\mathbf{8 0}$ & $\mathbf{1 2}$ \\
\hline
\end{tabular}

\section{Проработка экономической рентабельности проекта в П. Белая Гора, с. Оленёк и}

\section{с. Себян-Кюель}

Время эксплуатации МГЭС будет составлять около 4 месяца. Поэтому сроки окупаемости проектов будут довольно длинными из - за малой времени эксплуатации. Следует учесть фиксированные расходы предприятия (амортизация, заработная плата, эксплуатационные расходы), но существенно снижается потребление топлива ДГУ на летний период (конец 2 квартала - конец 3 квартала).

Таблица 4

\begin{tabular}{|c|c|c|c|c|}
\hline \multicolumn{5}{|c|}{ Фиксированные расходы в месяц } \\
\cline { 1 - 2 } $\begin{array}{c}\text { Населенный } \\
\text { пункт }\end{array}$ & $\begin{array}{c}\text { Заработная } \\
\text { плата, тыс.руб }\end{array}$ & $\begin{array}{c}\text { Амортизация, } \\
\text { тыс.руб }\end{array}$ & $\begin{array}{c}\text { Эксплуатационные } \\
\text { расходы, руб/кВт*ч }\end{array}$ & Итого, тыс.руб \\
\hline Белая Гора & 450 & 18,75 & & $\mathbf{4 6 8 , 7 5}$ \\
\hline Оленёк & 450 & 16,7 & 0,24 & $\mathbf{4 6 6 , 7 0}$ \\
\cline { 1 - 2 } $\begin{array}{c}\text { Себян- } \\
\text { Кюель }\end{array}$ & 290 & 21,0 & & $\mathbf{3 1 1 , 0 0}$ \\
\hline
\end{tabular}

Далее расчет сэкономленного топлива ДЭС по населенным пунктам, согласно данным ТЭП АО «Сахаэнерго»:

Таблица 5

\begin{tabular}{|c|c|c|c|c|c|}
\hline \multicolumn{5}{|c|}{ Сэкономленное топливо в РЭС за счет работы МГЭС } \\
\hline $\begin{array}{c}\text { Населенный } \\
\text { пункт }\end{array}$ & Июнь, тнт & Июль, тнт & Август, тнт & $\begin{array}{c}\text { Сентябрь, } \\
\text { тнт }\end{array}$ & Итого, тнт \\
\hline Белая Гора & 122,624 & 96,943 & 104,807 & 145,56 & $\mathbf{4 6 9 , 9 3 4}$ \\
\hline Оленёк & 117,684 & 85,486 & 108,327 & 172,029 & $\mathbf{4 8 3 , 5 2 6}$ \\
\hline $\begin{array}{c}\text { Себян- } \\
\text { Кюель }\end{array}$ & 13,883 & 11,959 & 12,78 & 20,165 & $\mathbf{5 8 , 7 8 7}$ \\
\hline \multicolumn{3}{|c|}{ Населенный пункт } & Итого (+ транспортные расходы 10\%), млн. руб \\
\hline 1. Белая Гора & \multicolumn{3}{|c|}{$\mathbf{1 8 , 4 0}$} \\
\hline \multicolumn{3}{|c|}{ 2. Оленёк } & $\mathbf{1 8 , 9 3}$ \\
\hline 3. Себян-Кюель & $\mathbf{4 , 2 5}$ \\
\hline
\end{tabular}

Следует рассчитать окупаемости данных проектов. В секторе «Прибыль» будет включен дополнительные средства, взятые из сэкономленных средств дизельного топлива (50\% - из экономии). 
Таблица 6

\begin{tabular}{|c|c|c|c|c|}
\hline \multicolumn{5}{|c|}{ Расчет окупаемости проекта. } \\
\hline $\begin{array}{c}\text { Населенный } \\
\text { пункт }\end{array}$ & $\begin{array}{c}\text { Прибыль от } \\
\text { потребителей э/э } \\
\text { за сезон, млн.руб }\end{array}$ & $\begin{array}{c}\text { Доп.вливании из } \\
\text { экономии } \\
\text { топлива, млн.руб }\end{array}$ & $\begin{array}{c}\text { Общий объем } \\
\text { вливаний за год, } \\
\text { млн.руб }\end{array}$ & $\begin{array}{c}\text { Срок окупаемости, } \\
\text { год }\end{array}$ \\
\hline Белая Гора & 1,6805 & 9,2 & 10,88 & $\mathbf{1 2}$ \\
\hline Оленек & 1,7295 & 4,7325 & 6,462 & $\mathbf{1 7 , 3 8}$ \\
\hline $\begin{array}{c}\text { Себян- } \\
\text { Кюель }\end{array}$ & 0,367 & 4,25 & 4,617 & $\mathbf{9 , 3 1}$ \\
\hline
\end{tabular}

В заключение моей работы хотелось бы сказать, что постройка МГЭС в условиях Крайнего Севера является вполне экономически и энергетически рентабельным проектом, но имеет значительные трудности и требует значительных инвестиционных вливаний со стороны инвесторов в лице государства или в лице частного капитала. Эти трудности заключаются в том, что средняя окупаемость такого вида проекта оценивается в размере 7 - 9 лет, сложная транспортная и социальная инфраструктура.

\section{Список литературы:}

1. Константинов А.Ф. Нетрадиционные энергоисточники Якутии/ Отв. ред.: Н.С. Бурянина. - Якутск: Изд-во ЯНЦ СО РАН, 2006. - 212с

2. www.rushydro.ru- Официальный сайт компании ОАО «Русгидро»

3. Кузин П.С. Классификация рек и гидрологическое районирование СССР. - Л.: Гидрометеоиздат, 1971. - 104c

4. Непорожний П.С., Обрезков В.И. Гидроэнергетические ресурсы. - М.: Энергоиздат, 1982. - 304c

5. Монахова И. Международный конгресс по нетрадиционной энергетике // Энергия:

6. Пополов А. Энергетика третьего тысячелетия // Снабженец. - 2001. №35. - С.5256

7. Безруких П.П. Что может дать энергия ветра // Энергия: экономика, техника, экология. - 2000. №2. - С. 13-24

8. Технико-экономические показатели РЭС северных районов РС(Я) на 01.01.2015 Министерство ЖКХ и энергетики РС(Я)

9. Технико-экономические расчеты в электроэнергетике. Методические рекомендации по экономическим расчетам в курсовых и дипломных проектах для студентов энергетического факультета. Министерство образования РФ ЯГУ им. М.К. Аммосова. 